\title{
Christian ethical perspectives on marriage and family life in modern Western culture
}

\author{
J M Vorster \\ School of Ecclesiastical Sciences \\ North-West University (Potchefstroomcampus)
}

\begin{abstract}
The past four decades witnessed a tremendous and wide-ranging change in family patterns in Western societies. Amongst these changes are phenomena such as growing number of divorces, births out-of-wedlock, and the absence of fathers because of globalisation, same-sex marriages and cohabitation of people without a marriage contract. Western societies are typified as "highdivorce societies". Furthermore, in the United States the number of couples cohabiting has increased eightfold since 1970 and it is fair to conclude that the situation is similar in other Western societies. The purpose of the article is to deal with these patterns from a Reformed perspective. The central theoretical argument is that these developments can be perceived as a crisis in view of the Biblical perspectives on marriage and family life. However, the Biblical perspectives not only offer a clear indication of healthy marriage and family life entail, but also indicate that a Christian attitude in marriage and family life can serve as a remedy for the damage caused by the new trends.
\end{abstract}

\section{INTRODUCTION}

The last four decades witnessed a tremendous and wide-ranging change in family patterns in Western societies. Among these changes are phenomena such as growing rates of divorce, out-of-wedlock births and father absence due to globalisation as well as same-sex marriages or civil unions and cohabitation of people without a marriage contract (Browning 2001:243). Western societies are typified as "high-divorce societies". Furthermore, the number of couples cohabiting has increased eightfold since 1970 in the United States and it is fair to conclude that the situation is similar in other Western societies. Gill (1997:81) expresses the concern of many Christians with his observation that we are "faced with a rapid decline in two-parent families, a 
rise in both teenage pregnancies and abortions, the spread of HIV/Aids, vociferous gay activism and widespread confusion about the legal and social limits of pornography and obscenity."

In a well documented article Browning (2001:4) finds that the phenomena of modernization and globalization are at the root of these disrupting forces in patterns of family-life. Should these developments be regarded as immoral or as normal cultural patterns in a changing society? Are they merely an indication of changes in family life or can they be regarded as part of a crisis ${ }^{1}$

In another equally well researched article, Browning (2001:247) refers to recent publications dealing with these questions and concludes that there has been a worldwide transformation in the attitudes within the social sciences towards these family changes since the late 1980s. He says that sociologists, psychologists and economists are much more willing to acknowledge nowadays that these developments have been damaging to large numbers of people. Changes in family patterns have contributed to the declining wellbeing of children and they have been concomitant with the "feminisation of poverty" (the shift of poverty from the elderly to single mothers and their children) as well as the "feminisation of kinship" (the trend towards women sustaining families alone, without the help of fathers and husbands). Although most social scientists now concur that these changes have been costly to individuals and society, they disagree about whether they can be reversed or whether they must simply be accepted in the hope of mitigating their negative consequences. Furthermore, Browning (2001:247) identifies three kinds of responses to this phenomenon in Christian ethical circles. These are liberal theological views that perceive these patterns as normal and in line with modern human rights sensitivities, the conservative theological view which regards them as immoral and contrary to biblical commandments and the Catholic view which is also conservative. ${ }^{2}$

The purpose of the article is to deal with these patterns from a Reformed perspective especially a revelation-historical hermeneutical approach. With regard to Christian ethical research and assuming a Christian point of view this approach entails the following line of reasoning:

- The recognition of the divine inspiration of Scripture and its authority for Christian faith and life.

\footnotetext{
${ }^{1}$ See the discussion of this question by Hauerwas (1981:155).

${ }^{2}$ For a thorough discussion of Roman Catholic views see Keane (1980).
} 
- The unity of the biblical message and the presence of continuous theological themes such as for example the covenant, kingdom of God, people of God, redemption and sanctification.

- The unfolding consistent revelation in the various genres of the biblical material against the background of the historical and cultural context of this material.

- The reading and understanding of a passage or text verse in Scripture within the framework of the whole revelation.

- The distinction between descriptive parts which narrates a certain historical happening or custom and the prescriptive parts that establish ethical principles and norms for modern-day conduct.

- The possibility to formulate clear principles from the prescriptive parts but also derived ethical principles from the underlying theological themes and unfolding revelation.

Taking this position I agree with the thesis of Browning (2001:14) that these modern developments in the field of family ethics are destructive and would argue that the Christian view of marriage and family can change marriage and family in the contemporary Western societies for the better. The central theoretical argument of this article is that the biblical perspectives on marriage and family-life perceive these developments as a crisis in society which should be dealt with by Christians and churches. The biblical perspectives not only offer a clear indication of healthy marriage and family life, but also entail that Christian attitude in marriage and family life can be a remedy to the damage caused by the new patterns.

The article will firstly present the most important biblical perspectives on marriage and family and secondly it will expound the implications of Christian attitude for these relationships. ${ }^{3}$ It will indicate that marriage and family together form a unique societal sphere of close relations. This unique sphere can be explained as a sphere of love, stewardship, self-denial and obedience and restoring this sphere will enrich family life at large and could provide a positive solution to the emerging crisis of our time.

\footnotetext{
${ }^{3}$ In a previous article I have written a commentary on $\mathrm{Ph} 2: 5$ regarding the attitude of Christ as a directive to the attitude of Christians. The conclusion of the article was that the attitude of a Christian should amounts to a life-style of love, stewardship, self-denial and obedience to God (see Vorster 2004:69).
} 


\section{MARRIAGE}

The biblical idea of marriage and family along the revelation-historical way of reasoning has the creational order as its foundation (Köstenberger 2004:31). Several principles arising from the creation of humankind have a determining meaning for the construction of family life in a biblical sense. The narrative in Gn 1-3 can be seen as the prototype of marriage and although other forms of marriages are described in the Bible, a revelation-historical survey of the biblical data regarding marriage reveals that the creational order should remain the ultimate test for this relationship. Both Jesus and the apostles refer to this order in their teachings about the essence of marriage and the responsibilities of husband and wife. Köstenberger (2004:31 \& 61) provides an extensive explanation of the relevant biblical material in his recent publication and I consider it unnecessary to deal with all the material in this article again. For the purposes of this article a short summary of the main principles regarding marriage and the important ethical norms will be provided. These are:

- God establishes marriage as a heterosexual monogamous marriage an exclusive relationship between one man and one woman (Douma 1993:113). Although polygamy was a custom in Old Testament times as it is evident in the lives of Lamech (Gn 4:19), Ezau (Gn 26:34), Abraham, David and Solomon, monogamy was the creational order. The historical accounts about polygamy must be seen as descriptive material but the creational order as prescriptive. This principle also forms the foundation of marital relations in the New Testament (1 Chr 7:2; Eph 5:28-33; Col 3:19 \& Tt 2:4). Polygamy is introduced in a descriptive way as a result of the fall while monogamy is introduced as prescriptive, in other words as the will of God. This creational order also excludes any notion of same-sex marriages.

- The purpose of marriage is primarily mutual help and guidance (Eph 5:23-25), physical and spiritual fulfilment and the prevention of immorality (1 Chr 7:1-7). According to Köstenberger (2004:98) procreation was also considered as an integral part of God's plan for marriage. He refers among other things to Genesis 1:28, 9:1 and $35: 11$. However, this point of view poses some ethical problems, because the childless marriage was not perceived as inferior. It seems that procreation is of secondary importance because a childless 
marriage can also be a blessing (Douma 1993:123). ${ }^{4}$ A couple can even choose not to have children in circumstances where the forming of a family may be detrimental to the well-being of the marriage or the society. The view of Hauerwas (2002:512) that Christians are called to marriage in order to build up the church is also problematic, even in the context of the remainder of his article. The same can be said of the opinion of Douma (1996:253) that voluntary childlessness conflicts with God's intention for marriage. He maintains that those who marry must be willing to have children. In my opinion, the view that the primary purpose of marriage is procreation, even for the sake of the church, reduces marriage to the sphere of the biological and inhibits the Christian to fulfil a responsible calling in society. When planning a family the well-being of the future children, the marital relation, the church and the society should be taken into account. For example, there will be no sense in having children and to subject them to a life of poverty and perennial despair. If it is ethically sound for a marital couple to plan the number of children, as Douma argues, they may also plan to have no children under certain circumstances. However, this planning should be done with responsibility in the light of the broad biblical perspective on marriage and family and the divine vocation of a family.

- The marital relation should be an intense relation on the spiritual and physical terrain. Husband and wife become one flesh and this means that two people share in each other's lives in a complete and dedicated manner. But marriage is more than sexuality. Marriage implies a deep spiritual relation because it is a triangular relation between man, wife and Christ (Eph 5:21-33). It is also more than a mere legal contract. It is a covenant between man and wife before God which is a harbinger of the covenant between God and his people (Douma 1993:114). This covenantal character of marriage entails that it is a sacred bond that is characterised by permanence, sacredness, intimacy, mutuality and exclusiveness Köstenberger, (2004:91). Douma (1996:266) is correct in his assessment that according to Scripture living together as man and wife always affects the broader community. Taking a woman as wife and a man as husband involved

\footnotetext{
${ }^{4}$ Douma (1993:123) argues this point thoroughly against the background of the views of Augustine and Barth regard procreation as the primary purpose of marriage. The problem with this view which was held for a long time in Christian ethics is that it reduces marriage to a mere physical relation and implies that the childless marriage is inferior.
} 
promises and duties toward God and man which were sanctioned before sexual union occurred.

- Marriage grows out of love between husband and wife and is maintained by love and faithfulness. Only love will make it possible for a couple to be compassionate, caring, committed, self-denying, selfsacrificing and forgiving. It is therefore difficult to found the practice of arranged marriages for whatever cause on the biblical message. Arranged marriages occurred in biblical history but never as prescriptive material for marriage ethics. For an ethical evaluation of arranged marriages the hermeneutical distinction of descriptive and prescriptive material is important to keep in mind.

- Man and woman were created in the image of God. This image of God founds the human dignity of human beings (Vorster 2004:93). However, this is not human dignity in the sense of inherent goodness, but a dignity, an esteem that God gives to humans (Ps 8). Montgomery (1999:7) indicates that God gives this dignity and esteem precisely because of $\sin$. From the likeness flow the responsibilities of people in this sinful dispensation. In spite of total depravity, God dignifies humans so that the sinful person in a broken world can act with dignity (Velema 1980:33; König 1993:61). This dignity comes to the fore in that God gives people duties (Heyns 1982:388).

- Children bear the same image and have the same human dignity. The human dignity of children is also founded on their creation in the image of God. This idea is central to anthropology in biblical faith. Fedler (2006:83) summarises the meaning of this concept with his conclusion that being created in the image of God means that God holds human beings in a very high regard. No human life is disposable. No human life can be used merely as a means to achieve some other end. Moreover, to be created in the image of God means that we are created to live in fellowship with God and human beings. Children share fully in this profoundly high view of human life as found in Scripture.

- The creation in the image of God founds the basic equality between man and woman. Brueggeman (1997:452) says that the fact that human beings are created in the image of God means that they have male and female characteristics, so that the communal, intersexual 
character of humankind is affirmed. The consequence of this point of view is that the equality brought about by the imago dei and the human's dominion over creation, is most important in the relation husband and wife.

- However, equality does not do away with the functional differentiation between men and women. God created male and female equally with only a functional differentiation in the sense that they have different obligations. ${ }^{5}$ The male person is the head of the household and should care for the family. The word used for "head" in Ephesians 5:23 is the same as the word used for Christ as the "head" of the Church. The word must be understood in view of the metaphor "Christ as the head and the Church as the body". Just as the head invigorates the body in an organic sense, Christ energizes the Church by way of the bestowment of the gifts of the Spirit. He is not the head in the sense of someone being the head of a corporation or the principal of a school. The husband is thus the head in a spiritual, "organic" sense. He does not rule with androgenic authority but should inspire, guide and being an example of obedience to God. His wife should assist him with the human family - not on the basis of subordination but of co-operation, as a help and a partner, because she bears the same image of God. But as Yahweh's partners, both have the same function in creation. Both are bestowed with the gifts of the Spirit and should use their gifts to fulfil their obligations regarding marriage and family. Any notion of the subordination of women in marriage cannot find support from a revelation-historical understanding of marriage in the context of Biblical theology.

- The divine foundation of marriage means that divorce mostly runs against the will of God. Furthermore, divorce violates the promise to commitment and the covenantal character of marriage which was witnessed by God and other people (Brueggemann 1997:452). It constitutes the breaking of a vow. Therefore, God forbids adultery in the seventh commandment. This prohibition includes divorce. But the seventh commandment and parallel passages should not be interpreted in a literalist way because God also made provision for divorce in certain circumstances. One reason for divorce can be when

\footnotetext{
${ }^{5}$ Adam and Eve were created in a marital relationship and their different roles pertain only to marriage. There is no reason to assert that the subordination of women is part of the creational order, which will mean that all male persons must rule over all women. This information qualifies the restriction put on women in 1 Timothy 2:11-13.
} 
the man finds something indecent in his wife (Dt 24:1). Due to the fundamental equality between husband and wife this provision will also apply to the wife finding something indecent in her husband. This "indecency" probably refers to sexual immorality and it concurs with the teaching of Jesus in the Sermon on the Mount which reads: "It has been said, 'anyone who divorces his wife must give her a certificate of divorce.' But I tell you that anyone who divorces his wife, except for marital unfaithfulness, causes her to become an adulteress, and anyone who marries the divorced woman commits adultery" (Mt 5:3132). Adultery signifies the breaking of an obedient relation with God and another human being (Bosman 2004:274). It has both religious and ethical consequences and serves therefore as a ground for annulment of a marriage. But other reasons for divorce can also be gathered from other biblical themes read within the context of revelation history. Wilful desertion can also be regarded as a valid reason for divorce (1 Cor 7:15-16), because desertion is de facto a breaking of a promise and of the covenant. Another reason for divorce will emerge when the actions of one partner inhibits the other partner to be obedient to God (Ac 4:19-20). These passages need further ethical reflection. Firstly, it does not mean that adultery must always lead to divorce. Forgiveness and reconciliation are also possible and must be pursued. Secondly, remarriage should be possible after repentance and forgiveness. If not, other teachings of the Scripture regarding forgiveness and reconciliation will be violated. Thirdly, when the conduct of one partner - for example addiction to alcohol and drugs, psychopathy, violence, sexual abuse and constant humiliation inhibits the other partner's relation with God, divorce may be permissible when all other remedies have failed. However, Douma (1996:275) warns correctly that divorce is always regrettable and surely remains an extreme measure.

\section{FAMILY}

With a literalist historical approach to the biblical material regarding family and family life a scholar will be able to describe the Christian family as a patriarchal family in the strict ancient sense. This idea determines the description of the family in some circles of conservative Christian communities indeed. However, when bringing the whole message of the Bible and revelation-history into play the picture changes. Then it becomes clear that the concept of a family is used in the biblical material in both an immanent concrete sense as well as in a spiritualist and transcendent sense (Moynagh 
1995:373). Each of these usages influences the other deeply. On the one hand, the family concept is used to describe the relation husband, wife and child. But the family is also used as a metaphor to describe the spiritual covenantal relation between God and his people. The people of God are a family, with God acting as Father and the believers as his children. The reason for this usage is that the relation between God and a believer is as close and loving as the relation between father and child in a family relationship. On the other hand the relation God-believer provides moral principles for family life. Moynagh researches the relevant biblical material from this revelation-historical hermeneutical point of departure and then concludes that this material actually emphasises several principles. His opinion as well as other conclusions that can be drawn from this metaphor can be summarised as follows:

- The family is deeply embedded in the idea of the covenant. The formula of the covenant expressed in Genesis 17:7 describes the essence of this relationship (Rendtorff 1998:11). God is the God of Israel and their descendants and they will be his people. This covenantal relationship contains promises and instructions. The covenant develops along familial lines. God promises his people that He will be their God but also the God of their children. The children are included in the covenant and this inclusion is signified by circumcision. The promise of the covenant, sealed by the initiating rite of circumcision, addresses itself to the solidarity of the family unit (Palmer Robertson 1980:152). The children thus have a special status which requires special treatment. This idea is equally important in the New Testament dispensation, as can be seen in Jesus' special concern for the children and the fact that baptism replaces circumcision as the sign of the covenant. The doctrine of salvation and especially the biblical view that children share fully in the salvation in Christ complement this idea. Children are also justified by faith and receive the gift of faith just as much as adult believers. These gifts of grace are signified by the sacrament of baptism. In the theology of Paul baptism is seen as the baptism in the death and resurrection of Christ (2 Cor 5:14-15) (Ridderbos 1971:225).

- In the family of God relationships are characterised by equality. This observation corresponds with the implication of people being created in the image of God. Husband, wife and children are essentially equal and 
have the same rights and responsibilities before God. Therefore, this equality must be expressed and nurtured in a family relationship.

- In the family of God people are equal before God but that does not entail uniformity. Just as the people of God are blessed with different gifts, members of a family are blessed with diversity in nature, talents, spiritual gifts and customs. The diversity does not inhibit the equality but should enrich it. In the functioning of this unique community the individuals should honour each other's sameness and otherness on the foundation of their inherent equality before God. This principle implies mutual submission (Moynagh 1995:373).

- In the family of God people share their spiritual and material gifts. Therefore, a family ought to be a sharing community in a spiritual, emotional and material sense.

- In the family of God believers reflect unity and thus models family solidarity. Solidarity implies mutual compassion, responsibilities, obedience within the culture of functional differentiation between husband, wife and child. The "household codes" reflect this functional differentiation in the broader framework of solidarity (Eph 5:21-6:9).

\section{AN AUTOGENOUSLY INSTITUTION}

Contrary to the idea of Plato and Aristotle that the family is a component of the state, the biblical revelation-history teaches that God established different spheres of authority due to the fall and the maintenance of order in society. While the Graeco-Roman culture defines the family within the framework of the state, the New Testament defines the family within the framework of the covenant and kingdom of God. In the Graeco-Roman concept the family exists for the benefit of the state and derived its moral principles from this prerequisite. In the New Testament the family is seen as part of the kingdom of God and derives its moral basis from God's commands. The smallest circle of authority that God grants is thus the authority in the circle of the family. God creates man and woman and the family and he provides clear principles for the function, purpose and management of the family. These principles are reinforced in the New Testament, especially with regard to Christ's reconciliatory work that forms the basis of a good marriage and good family relationships. 
On the foundation of this principle, the Reformed philosophy developed a pluralistic societal philosophy in which societal contexts each exercise its own authority alongside each other (Stackhouse 1995:26). Within this philosophy two kinds of societal contexts are identified namely institutional contexts and free associations. Institutional contexts comprise those that God Himself instated, including marriage, family, the church and the state. Free associations are societal contexts that developed historically such as the school, political parties, unions, societies and clubs, etcetera (Van der Walt 1999:104). In this respect the family is characterised as a societal relation in its own right with moral instructions to the husband, wife and children (Whang 1998:91). The fulfilment of these obligations serves not only God but also the well-being of this societal relation which then functions as a sphere of authority in its own right.

Therefore, the family must be viewed in Christian ethics as an autogenously institution. The family does not belong to the state or any other institution. Marriage and family relations should not be controlled by other societal spheres such as the civil authority, the church, the extended family or the tribe.

On the other hand, while the family is a sphere of authority in its own right, it functions within the boundaries of the laws of the civil authority. For the well-being of society and for the protection of the rights of men, women and children before the law, a civil authority has to define and recognise a family. Spheres of authority in the reformed idea of societal relations function independently, each with an own moral basis and destiny, but they are also dependent on each other. Although the family is independent it can never be above the law.

Therefore the family should also be regarded as a public institution. Although no instructions can be found in biblical times that marriage could only be regarded as a marriage when it was officiated by an organ of the civil authorities, marriage was also not viewed as a private matter. This truth is proved by the fact that the extended family as well as fellow believers were deeply involved (Douma 1993:133). As a result of the development of societal spheres of authority in history, the mutual dependence and interaction between the various spheres of authority shaped the idea that marriage must also be a public institution.

In this instance I would argue as follows: in the case of Christians the marriage should be a marriage "in the Lord" and the local congregation should act as witnesses that this is indeed he case. The promises of the future husband and wife to a life-long commitment are made to God with the fellow believers as witnesses. The family also acts as witnesses. While the parties in 
a marriage and the future family that develops out of this marriage have certain fundamental human rights, which should be protected by the civil authorities and other spheres of authority, the official recognition of a marriage by these societal structures is very important. Therefore marriage should be a legal union in terms of the law of the civil authority.

The modern custom of cohabitation can therefore be questioned from a Christian ethical perspective. When a couple disregards the involvement of the fellow Christians as witnesses of the vow, the civil authorities and the extended family, a very important part of the Christian concept of a marital relation is neglected. Cohabitation also neglects the importance of a vow. It is very interesting to note that this deficiency becomes apparent when the social implications of cohabitation are evaluated. Some trends in modern societies seem to prove the value of the Christian message. Browning (2001:10) refers to research that established that in the United States a significant portion of children born from cohabiting relationships are on the average much more fragile than children from legal marriages. He also points out that studies conducted in Sweden about cohabiting couples with one child indicate that the dissolution rate is three times as high for them as it is for legally married couples with one child. A couple's legal commitment to the formal institution of marriage based on the vow of a life-long dedication appears to be an integral part to the stability of the union.

Taking these principles into account, the implications of a Christian attitude for marriage and family-life can be investigated. A Christian attitude entails that marriage and family should be spheres of love, stewardship, selfdenial and obedience to God.

\section{A SPHERE OF LOVE}

Love manifests itself in terms of family life as a responsible partnership between husband and wife as well as in parenthood and childhood. Responsible partnership is rooted in the principle that "a man will leave his father and mother and will be united with his wife, and they will become one flesh" (Gn 2:24). The other biblical principles guiding the relationship in marriage determine that this phrase "united with his wife" cannot be limited to a sexual relationship but rather that it points to a loving partnership that should materialize fully in all spheres of life. Another facet of this partnership is that husband and wife are equal but with a functional differentiation. This differentiation also pertains to their respective obligations in marriage.

The household codes comprise the leading principles in this partnership (Eph 5:22-33). Due to the fact that marriage is a depiction of the relationship between Christ and his church, husbands should love their wives 
and should be willing to make sacrifices to the benefit of the marital relationship. Furthermore, they should not exasperate their children and should bring them up in the training and instruction of the Lord. Wives must love and honour their husbands and should be examples of purity and reverence (1 Pt 3:1-7).

This partnership is the only sphere of human sexuality. Sexual relations cannot be viewed as a private matter between two individuals for the purpose of the fulfilment of intrinsic sexual desires. Hauerwas (2002:484) comments correctly that the claim that sex is a matter of private morality is a political claim dependent upon a liberal political ethos. In a recent thorough study of sexuality conducted within the framework of human dignity, Vorster (2004:893) concludes that sexuality is essentially a component of marriage because of the fact that it is rooted in multidimensional relations - the relation between husband and wife and the relation of both of them with Christ. It is also deeply embedded in the human dignity of human beings due to their creation in the image of God. Therefore sexuality runs deeper than the physical features that allow the reproductive function (McCormick \& Connors 2002:170).

Sexuality is more than eros. It pertains to the deepest levels of our personality, entails a psychological spiritual and biological dimension, influences a human being's every act and determines our total response to life. Sexuality is therefore eros and agape. Where eros and agape merge, the highest form of love emerges. Therefore, sexuality without love and the security of the marital relation can be a violation of human dignity. This biblical perspective on sexuality reaffirms the notion that sexuality can only function in its true meaning within the confines of a marital relation which is a covenantal relation characterised by faithfulness and permanence. In their sexual relations husband and wife express their mutual love, but also their mutual partnership in the body of Christ (1 Cor 6:12-20). Their bodies are part of the body of Christ and loveless sex violates this spiritual relationship.

Responsible parenthood entails the loving, nurturing and teaching of children by both father and mother. Scripture provides many principles and norms with regard to the purpose of Christian instruction within the confinements of the covenant. In this respect also the book of Köstenberger (2004:104) provides valuable information. In broad terms the task of parents has to do with the great commandment. Parents should teach their children to love God and to love their fellow human beings. This major teaching further comprises certain specific purposes and these are adequately summarised by Köstenberger in his discussion of the relevant passages as found in the book Proverbs. The purpose of Christian instruction to children within the Christian family should be to teach them the attributes of: 
- diligence and industriousness ( $\operatorname{Pr} 6: 6-11 ; 11: 27 ; 12: 24 ; 13: 4 ; 15: 19$; $18: 9 ; 19: 24,13 ; 21: 5 ; 22: 13 ; 26: 13-16)$,

- justice (Pr 11:1; 16:11; 17:23; 20:10, 23; 31:8-9),

- kindness ( $\operatorname{Pr} 11: 17)$,

- generosity (Pr 11:24; 19:6),

- self-control, particularly of speech ( $\operatorname{Pr} 12: 18 ; 13: 3 ; 21: 23)$ and temper (Pr 14:17, 29; 15:18; 16:32; 19:11; see also 25:28),

- righteousness (Pr 12:21, 28; 14:34),

- truthfulness and honesty (Pr 12:22; 16:13; 24:26),

- discretion in choosing friends ( $\operatorname{Pr} 13: 20 ; 18: 24)$, particularly a spouse (Pr 18:22; 31:10-31),

- caution and prudence (Pr 14:16; 27:12),

- gentleness (Pr 15:1, 4),

- contentment (Pr 15:16-17; 16:8; 17:1),

- integrity of character ( $\operatorname{Pr} 15: 27 ; 28: 18)$,

- humility (Pr 16:19; 18:12; 22:4),

- graciousness (Pr 16:24),

- forthrightness (rather than duplicity; $\operatorname{Pr} 16: 30 ; 17: 20$ ),

- restraint (Pr 17:14, 27-28; 18:6-7; 29:20),

- faithfulness in friendship ( $\operatorname{Pr} 17: 17)$ and other relationships ( $\operatorname{Pr} 28: 20)$,

- purity ( $\operatorname{Pr} 20: 9 ; 22: 11)$,

- vigorous pursuit of what is good and right ( $\operatorname{Pr} 20: 29)$,

- skilfulness in work (Pr 22:29),

- patience (Pr 25:15).

All these are necessary for the fulfilment of the great commandment.

The fifth commandment is the foundation of responsible childhood. Children should honour their parents and be obedient. According to Douma (1996:105) this honour has several components. Children should take to heart the instruction of their parents, they should love them and they should be faithful. This obligation to honour parents never falls away - not even when the children reach adulthood.

\section{A SPHERE OF STEWARDSHIP}

Life is religion. This basic Reformed dictum unfolds the conviction that Christians are always and everywhere in the active service of God. They serve God in politics, culture and economics, on the field of sport and recreation and in business and their daily occupation. Every action is an action in the service and to the honour of God. The reign of God and the 
present reality of the Kingdom implies that there is no neutral ground or area under own control. This truth determines marriage and family. Christians are first and foremost stewards of each other in their marital and familial relations.

This stewardship in the household transforms the human inclination to be egoistic and selfish into a spirit of giving. When people start to share their emotions, feelings, hopes, gifts and talents, experiences and fears, they engage in positive, building of relationships.

Stewardship is a unique Christian ethical principle. It reminds the individual to be there, to build, to share, to provide and to be co passio (compassionate). This principle brought a fresh breeze into the family structure of the Graeco-Roman world of biblical times. Browning (2001:14) is correct with his assessment that Early Christianity fractured and qualified the honour-shame codes of Graeco-Roman life by celebrating male servanthood rather than male dominance, by applying the golden rule of neighbourly love to relationships between husband and wife, by requiring males to renounce their sexual privileges with female slaves and young boys, and by elevating the status of women. This is still true in the modern world. The stewardship quality in Christian marriage and family life can break the many negative trends of our time that have been mentioned earlier in this article.

\section{A SPHERE OF SELF-DENIAL}

Stewardship can be effective only when it is accompanied by the attitude of self-denial. Ephesians 5:21 expresses the calling to self-denial in the Christian marriage and family. This passage reads: "Submit to one another out of reverence for Christ". Some texts regard this passage as part of the pericope Ephesians 5:6-21 which deals with the general relation between believers as part of their Christian conduct (Aland 1965:676). Others regard it as part of the pericope Ephesians 5:22-33 which will then mean that the call to mutual submission comes specifically to husband and wife. Conservative scholars usually tend to hold on to the first meaning because the second opinion contradicts in their view the direct call upon wives that they have to submit to their husbands. More progressive scholars are of the opinion that the second interpretation is more to the point and indicates that this passage clearly runs against any justification of a patriarchal family structure.

However, the question can rightly be asked whether one's interpretation makes any difference. Foulkes (1968:154) holds on to the first opinion but says that Paul knew from experience that the secret of maintaining joyful fellowship in the community was the order and discipline that came from the willing submission of one person to another. Pride of position and the authoritarian spirit are destructive for fellowship. The importance to Paul of the 
whole concept of submission is evident from the use of the word more than twenty times in his Epistles. Surely even when one perceives this instruction as pertaining to all the social relations between Christians it will address husband and wife and also parents and children. What does this instruction mean? In my opinion it teaches Christians:

- to be constantly aware of the fact that they are living in particular relations with other people,

- that people are differently gifted by God for the purpose of fulfilling a calling in the Kingdom,

- that other people's gifts can enrich my life and could change my life for the better,

- that Christians should submit themselves to each other in order to be enriched by the gifts and talents of others,

- that there must be a willingness in the Christian fellowship to serve any, to learn from any, to be corrected by any, regardless of age, sex, class or any other division (Foulkes 1968:154).

For a husband and wife this instruction entails that they have to be submissive to each other in the spheres of marriage where they are differently gifted by the Holy Spirit. For example, if the wife has the gift of teaching, the husband should leave the basic instruction of the children to his wife. In this way the basic functional differentiation in the marital relationship can be employed to enrich the marriage. Although the basic function of the husband to be the head of the household and the wife to assist are fixed, the execution of these functions can differ from household to household. The basic functions are fixed for husband and wife but the execution thereof depends on the variety of gifts bestowed on each of them. Therefore, functions can also differ from household to household within the broader framework of the creational order of functional differentiation. The function of the mother in one household may differ from the function of a mother in another household because they are gifted in different ways.

The willingness to learn form each other is the essence of self-denial in Christian relations and especially in family relations. But self-denial also has other important implications. It means that family members should be willing to sacrifice. The father may sometimes sacrifice promotion at work for the sake of his wife and children. The mother may sacrifice the ideal to have another child or to follow a professional career for the sake of the well-being rest of the family. Children should sometimes be willing to sacrifice opportunities for the sake of family interests. Family members have to be willing to sacrifice 
material gains if these prospects infringe upon the happiness of the family. Self-denial is the key to a compassionate family.

\section{A SPHERE OF OBEDIENCE}

Marriage and family are indispensable components of God's intention for fallen humanity. He carries redemption and renewal by way of his coming Kingdom and the covenant with people and their children. Obedience to God encompasses the totality of the life of a believer. Therefore, the family should be seen as a sphere where the reign and authority of God should prevail. The reign of Christ stretches to the deepest corners of this intimate social relation. Marriage and family life in Christian circles cannot be determined by nature or culture but only by the moral teachings of Scripture.

Post-modern culture challenges this idea. There is a tendency in Christian circles to condone modern customs regarding marriage and family and to relativise the distinctiveness of Christian morality. Gill (1997:86) detects and laments this tendency in the well-known 1995 report of the Church of England's Board for Social Responsibility (1995). He warns against the "baptising of a purely secular agenda". Still he regards certain modern trends as not inherently sinful in terms of Christian virtues but "less than ideal". According to him these are childlessness through spontaneous sterility, faithful cohabitation and faithful homosexual relationships.

However, in my opinion this "less than ideal approach" with respect to faithful cohabitation and homosexual relationships must eventually also lead to a "baptism of the secular" because it compromises the authority of God and the reign of Christ over marriage and family. It will introduce a pragmatic, situation-oriented ethics that will in the end abolish Christian moral distinctiveness and pave the way for complete secularity. To my mind Christian churches today have the responsibility to proclaim the core values of marriage and family life and to protect this societal sphere even if it runs directly against the ethos of the new post-modernist worldview. To live according to the attitude of Christ means to be obedient to God in all spheres of life - also in marriage and family life in modern circumstances.

\section{CONCLUSION}

When marriage and family are seen together as the sphere in which the core characteristics of a Christian attitude prevail, modern negative trends in family life can be addressed. The sphere of love is the answer to so many broken homes with their hopelessness, loneliness and despair. Stewardship in family life reminds parents and their children that serving their family is part of their 
service in God's Kingdom. Self-denial opposes all forms of selfishness and transforms the receiving hand into a giving hand and the spirit of selfishness into compassion. In this way it provides the bonding material for good interpersonal relations in the household. Obedience to God is not only the remedy for unhealthy families, but also the characteristic of a sound marriage and family that reflect the holiness of God and the beauty of his constant renewal of this broken and incomplete world.

\section{Works consulted}

Aland, K 1965, The Greek New Testament. London: United Bible Societies.

Bosman, $\mathrm{H}$ 2004. Adultery, prophetic tradition and the decalogue, in Brown, W P (ed), The Ten Commandments: The reciprocity of faithfulness, London: Westminster John Knox.

Browning, D 2001. The world situation of families: Marriage reformation as a cultural work. Edinburgh: T \& T Clark

Browning, D 2001. World family trends, in Gill, R (ed), The Cambridge Companion to Christian Ethics, 243-260. Cambridge: Cambridge University Press.

Brueggemann, W 1997. Theology of the Old Testament, testimony, dispute, advocacy. Minneapolis, MN: Fortress.

Church of England 1995. Something to celebrate: Valuing families in church and society, London: Church House.

Douma, J 1993. Seksualiteit en huwelijk. Kampen: Uitgeverij van den Berg.

Douma, J 1996. The Ten Commandments: Manual for the Christian Life. Phillipsburg, NJ: P \& R Publishing.

Fedler, K D 2006. Exploring Christian Ethics, Biblical foundations for morality. Westminster: John Knox.

Foulkes, F 1968. Ephesians: An introduction and commentary. London: Tyndale.

Gill, R 1997. Moral leadership in a postmodern age. Edinburgh: T \& T Clark.

Hauerwas, S 1981. A community of character, toward a constructive Christian social ethic. London: Notre Dame.

Hauerwas, S 2002. The Hauerwas reader. Durham: Duke University Press.

Heyns, J A 1982. Teologiese etiek, deel 1. Pretoria: NG Kerkboekhandel.

Keane, P S 1980. Sexual morality: A Catholic perspective. Dublin: Gill \& Macmillan.

König A 1993. Menslike mense: Gelowig nagedink, deel 5: Oor die mens en die sonde in praktyk. Halfway House: Orion.

Köstenberger, A J 2004. God, marriage and family: Rebuilding the Biblical foundation. Wheaton, IL: Crossway.

Mc McCormick, P T \& Connors, R B 2002. Facing ethical issues, dimensions of character, choices and community. New York: Paulist.

Montgomery, J W 1999. Een bijbelse fundering voor menschenrechten en voor menselijke waardigheid. De Beweging 1, 7.

Moynagh, M 1995. Family, in Atkinson, D J (ed) et al, New Dictionary of Christian Ethics and Pastoral Theology. Leicester: Inter-Varsity Press,

Palmer R O 1980. The Christ of the covenants. Phillipsburg, NJ: Presbyterian and Reformed Publishing Co. 
Rendtorff, R 1998. The Covenant formula, an exegetical and theological investigation. Edinburgh: T \& T Clark.

Ridderbos, H 1971. Paulus, ontwerp van zijn Theologie. Kampen: Kok.

Stackhouse, M L 1995. Christian social ethics in a global era: Reforming Protestant views, in Christian social ethics in a global era. Nashville, TN: Abingdon.

Van der Walt, B J 1999. Naby God: Christus en kerk op die drumpel van spiritualiteit. Potchefstroom: Potchefstroomse Universiteit vir Christelike Hoër Onderwys.

Velema, W H 1980. Discussie over menchenrechten Apeldoorn: Willem de Zwijgerstichting.

Vorster, J M 2004a. Ethical perspectives on Human Rights. Potchefstroom: Potchefstroom Theological Publications.

Vorster, J M 2004b. The attitude of Christ as a principle for modern Christian ethics seen from a classic Reformed perspective. Studia Historia Ecclesiasticae XXX(2), 48-73

Vorster, N 2005. Human dignity and sexual behavior - A theological perspective, Verbum et Ecclesia 26(3), 891-911.

Whang, Y C 1998. Cohabitation or conflict: Greek household management and Christian Haustafeln, in Hayes, M A et al. Religion and Sexuality. Sheffield: Sheffield Academic Press. 